\title{
PENGARUH MULTIPLE REPRESENTATION PADA PEMBELAJARAN BERBASIS MASALAH TERHADAP PENGUASAAN KONSEP FISIKA DASAR II MAHASISWA FISIKA
}

\author{
Chandra Sundaygara*, Denanda Gaharin \\ Program Studi Pendidikan Fisika,Universitas Kanjuruhan Malang, Indonesia
}

\begin{abstract}
The purpose of this study is to determine the effect of multiple representation on problembased learning (PBL) on the mastery of basic physics concept 2 . Tyoe of research is quasy experiment using postest only control group design. The subject of the study consisted of two group which the experimental group of students who studied with the PBL with multiple representation of 1 class and control group of students who studied with PBL. Data nastery of basics physics concept 2 through from the student's test after got treatment. The result of this study indicate that the mastery basic concept 2 of student who learn with PBL model with multiple representation higher than students who learn with PBL
\end{abstract}

Keywords: Basic Physics Concept 2; Multiple Representation; Problem Based Learning

\begin{abstract}
Abstrak
Tujuan penelitian ini adalah untuk mengetahui pengaruh multiple representation pada pembelajaran berbasis masalah (PBM) terhadap penguasaan konsep fisika dasar 2. Jenis penelitian ini adalah quasi eksperimen menggunakan posttest only control group design. Subyek penelitian dipilih secara random klaster. Subyek penelitian terdiri dari 2 kelompok yaitu kelompok eksperimen yaitu mahasiswa yang belajar menggunakan model pembelajaran berbasis masalah dengan multiple representation 1 kelas dan kelompok kontrol yaitu mahasiswa yang belajar dengan model pembelajaran berbasis masalah 1 kelas. Data penguasaan konsep fisika dasar 2 diperoleh melalui tes yang dilaksanakna setelah Mahasiswa mendapat perlakuan. Hasil penelitian menunjukkan bahwa penguasaan konsep fisika dasar 2 mahasiswa yang belajar dengan model pembelajaran berbasis masalah dengan multiple representation lebih tinggi dibandingkan siswa yang belajar dengan pembelajaran berbasis masalah
\end{abstract}

Kata Kunci: Multiple Representation, Pembelajaran Berbasia Masalah, Penguasaan Konsep Fisika Dasar 2

DOI : http://dx.doi.org/10.21067/mpej.v1i2.1863

Diterima: Agustus 2017; Disetujui: September 2017

\section{PENDAHULUAN}

Pembelajaran berbasis masalah adalah salah satu pembelajaran yang dapat diimplementasikan untuk mencapai capaian atau tujuan

* Corresponding Author:

chandrasundaygara@gmail.com pembelajaran fisika (Dirjen Dikti

Kemendikbud, 2014). Pembelajaran berbasis masalah adalah suatu model pembelajaran yang menggunakan masalah dunia nyata sebagai suatu konteks untuk mengembangkan 
keterampilan pemecahan masalah mahasiswa (Akinoglu dan Tandogan, 2007; Arends, 2008). Pembelajaran berbasis masalah akan membuat mahasiswa aktif karena mahasiswa pada awal pembelajaran dihadapkan pada masalah dunia nyata dan memecahkan masalah melalui kerja kelompok (Belgin, 2009; Pepper, 2009 ). Pembelajaran berbasis masalah akan dapat meningkatkan penguasaan konsep dan kemampuan pemecahan masalah mahasiswa dibandingkan dengan pembelajaran konvensional (Selcuk, 2010; Bilgin, dkk, 2009; Folashade dan Akinbola, 2009). Ketika mahasiswa memiliki kemampuan pemecahan masalah yang baik, maka akan memberikan dampak pada pencapaian penguasaan konsep yang lebih baik (Nieminen, dkk, 2012 ).

Pada pembelajaran berbasis masalah mahasiswa terdapat beberapa permasalahan yang timbul yaitu mahasiswa akan kesulitan memahami permasalahan yang disajikan dan kesulitan memecahkan masalah. Kesulitan memhami dan memecahkan masalah dialami oleh mahasiswa yang mempunyai pemahaman konsep dan daya rendah
(Selcuk, 2010). Kesulitan memahami dan menyelesaikan masalah disebabkan karena mahasiswa terbiasa menyelesaikan soal matematis yang hanya menggunakan rumus matematis dalam penyelesaiannya (Docktor, dkk, 2011; Jonassen, 2011) Kesulitan mahasiswa dalam memahami dan menyelesaikan masalah akan menyebabkan pemecahan masalah memerlukan waktu yang lama (Kelly, 2007). Kesulitan memecahkan masalah mahasiswa dapat diatasi dengan pemberian bantuan kognitif (cognitive scaffolds). Bantuan kognitif akan membantu mahasiswa memahami permasalahan yang disajikan dan membantu memecahkan (Jonassen, 2011). Salah satu bantuan kognitif (cognitive scaffolds) yang dapat diberikan kepada mahasiswa adalah penggunaan metode multiple representation.

Multiple representation adalah suatu cara penyajian konsep atau teori melalui berbagai cara yaitu dengan menggunakan representasi gambar, representasi verbal, representasi matematis, dan representasi grafik (Ainsworth, 
2008). Penggunaan dapat membantu siswa memahami dan mengevaluasi pemecahan masalah yang dikerjakan (Rosengrant $d k k, \quad 2009)$ karena penggunaan multiple representation akan dapat menggambarkan konsepkonsep yang abstrak menjadi lebih konkrit. (Podoleftsky dan Finkelstein, 2006 dalam Sundaygara, 2014). Pemecahan masalah yang baik akan berdampak pada penguasaan konsep yang baik (Sundaygara, 2014) Hasil penelitian menunjukkan bahwa penggunaan multiple representation dalam pembelajaran membantu meningkatkan penguasaan konsep (Sundaygara, 2014; Lovisa, 2010; Rosengrant, dkk, 2009; Kohl, dkk 2007).

Di negara lain telah banyak melakukan penelitian tentang aplikasi multiple representation pada pembelajaran fisika pada materi mekanika. Aplikasi multiple representation pada pembelajaran memberikan pengaruh yang baik kepada mahasiswa antara lain: (1) membantu memecahkan masalah yang dihadapi, (2) membantu mengembangkan penguasaan konsep fisika membantu mahasiswa dalam menafsirkan dan menggambarkan ide dari konsep fisika maupun permasalahan fisika yang bersifat abstrak menjadi lebih konkrit, (3) mengembangkan kemampuan pemecahan masalah fisika pada konteks yang berbeda (Sundaygara, 2014). Akan tetapi, aplikasi multiple representation pada pembelajaran berbasis masalah masih dan pada materi fisika dasar II jarang dilakukan, sehingga diperlukan penelitian tentang pengaruh multiple representation pada pembelajaran berbasis masalah terhadap penguasaan konsep fisika pada fisika dasar 2 mahasiswa fisika.

\section{METODE}

Jenis penelitian ini adalah kuasi eksperimen dengan menggunakan posttest-only control group design. Desain penelitian disajikan pada Tabel 1.

Subyek penelitian ini adalah mahasiswa fisika Universitas Kanjuruhan Malang angkatan 2016/2017 yang terdiri dari 3 kelas. Kemudian dipilih 1 kelas untuk kelompok eksperimen dan 1 kelas untuk kelompok kontrol dengan metode random klaster. Kelompok 
eksperimen yaitu mahasiswa angkatan 2016/2017B yang diajar dengan menggunakan pembelajaran berbasis masalah dengan multiple representation, sedangkan kelompok kontrol yaitu mahasiswa fisika angkatan 2016/2017A yang diajar dengan model Pembelajaran berbasis Masalah. Penelitian dilaksanakan pada semester genap tahun ajaran 2016/2017. Instrumen penelitian terdiri atas RPS, LKS, dan tes penguasaan konsep fisika.

Tabel 1. Desain penelitian

\begin{tabular}{|c|c|c|}
\hline \multirow[t]{2}{*}{ Kelompok } & Perlakuan & $\begin{array}{c}\text { Sesudah } \\
\text { perlakauan }\end{array}$ \\
\hline & & PK \\
\hline
\end{tabular}

\begin{tabular}{cl}
\hline Eksperimen & $\mathrm{X}$ \\
\hline Kontrol & -
\end{tabular}

Keterangan:

X: Perlakuan

PK: Penguasaan konsep

Data penguasaan konsep didapatkan melalui posttest yang dilakukan setelah siswa mendapat perlakuan. Data penguasaan konsep kemudian diuji prasyarat. Uji prasyarat yang dilakukan adalah uji normalitas menggunakan uji lilifors dan uji homogenitasmenggunakan uji
Harley. Uji hipotesis penelitian menggunakan uji-t.

\section{HASIL DAN PEMBAHASAN}

Sebelum mahasiswa diberi perlakukan, dilakukan uji kemampuan awal untuk mengetahui apakah kemampuan awal mahasiswa sama atau tidak. Data kemampuan awal diperoleh dari nilai ujian akhir fisika dasar I yang telah ditempuh mahasiswa sebelumnya. Data kemampuan awal mahasiswa digunakan untuk mengetahui apakah kemampuan awal mahasiswa sama sebelum diberi perlakuan. Data penguasaan konsep mahasiswa disajikan pada Tabel 2.

\section{Tabel 2. Data Kemampuan Awal}

\begin{tabular}{lcc}
\hline Keterangan & N & Rata-rata \\
\hline Kelompok & 31 & 58.36 \\
eksperimen & & \\
\hline Kelompok Kontrol & 32 & 58.09 \\
\hline
\end{tabular}

Berdasarkan data pada tabel 2 diketahui bahwa nilai rata-rata kemampuan awal mahasiswa antara kelompok eksperimen dan kelompok kontrol hampir sama. Selanjutnya data kemampuan awal diuji prasyarat 
yaitu uji normalitas dan uji homogenitas.

Hasil uji normalitas data kemampuan awal menunjukkan bahwa nilai signifikansi kelas eksperimen (0.596) > taraf signifikan (0.05) dan nilai signifikan kelas kontrol (0.897) > taraf signifikan (0.05). Berdasarkan uji normalitas disimpulkan bahwa data terdistribusi normal. Uji homogenitas menunjukkan bahwa nilai signifikansi (0.995) > taraf signifikansi (0.05). Berdasarkan uji homogenitas dapat disimpulkan bahwa data kemampuan awal homogen.

Setelah uji prasyarat, maka dilakukan uji statistik. Uji statistik menggunakan uji-t. Data hasil uji-t disajikan pada Tabel 3.

Tabel 3. Hasil Uji-t

\begin{tabular}{lcc}
\hline \multicolumn{3}{l}{ Kemampuan Awal Mahasiswa } \\
\hline \multicolumn{2}{l}{ Nilai sig perhitungan } & 0.955 \\
\hline Taraf signifikan $(a)$ & 0,05 \\
\hline Hasil uji-t & pada & Tabel 3 \\
menunjukkan & bahwa & nilai \\
signifikansi yaitu & $0.995 \quad>$ & taraf \\
signifinasi yaitu & $0.05 . \quad$ Hasil & uji-t \\
menunjukkan bahwa H0 diterima dan
\end{tabular}

Ha ditolak yang berarti bahwa tidak ada perbedaan kemampuan awal antara kelompok eksperimen dan kelompok kontrol. Hal ini menunjukkan bahwa kemampuan antara kelompok eksperimen dan kelompok kontrol adalah sama.

Data Penguasaan konsep fisika dasar 2 diperoleh setelah kedua kelompok yaitu kelompok eksperimen dan kelompok kontrol mendapat perlakuan. Data penguasaan konsep kelompok eksperimen dan kelompok kontro disajikan pada Tabel 4.

Tabel 4. Deskripsi Data Penguasaan Konsep Fisika Dasar 2

\begin{tabular}{llll}
\hline Kelompok & $\mathrm{N}$ & Mean & $\begin{array}{c}\text { Std. } \\
\text { Deviation }\end{array}$ \\
\hline Eksperimen & 31 & 70.74 & 11.74 \\
\hline Kontrol & 32 & 62.78 & 14.59 \\
\hline
\end{tabular}

Berdasarkan Tabel 4 diketahui bahwa rata-rata nilai penguasaan konsep fiska dasar 2 kelompok kontrol lebih tinggi dibandingkan dengan kelompok kontrol. Selanjutnya data penguasaan konsep fisika dasar 2 diuji prasyaratyaitu uji normalitas dan uji homogenitas. Pengujian normalitas data 
penguasaan konsep fisika dasar 2 pada kelompok eksperimen diperoleh nilai signifikansi $=0,102>$ Taraf signifikansi $=0.05$ dan data penguasaan konsep fisika dasar 2 kelompok kontrol memperoleh nilai signifikansi $=0,099>$ taraf signifikansi $=0.05$. Hasil uji normalitas menunjukkan bahwa data kelompok eksperimen dan kelompok kontrol terdistribusi normal. Pengujian homogenitas data variabel penguasaan konsep fisika dasar pada kedua kelas diperoleh nilai signifikansi $=0.307>$ Taraf signifikansi $=0.05$, sehingga dapat disimpulkan bahwa kedua kelompok data tes penguasaan konsep fisika dasar 2 adalah homogen.

Ada tidaknya perbedaan penguasaan konsep fisika dasar 2 dapat diketahui menggunakan uji-t. Hasil analisis data menggunakan uji-t disajikan pada Tabel 5.

Tabel 5. Hasil Uji-t Penguasaan Konsep Fisika Dasar 2

\begin{tabular}{lc}
\hline \multicolumn{2}{c}{ Penguasaan } \\
\hline Nilai Sig & 0.02 \\
\hline Taraf Sig & 0.05 \\
\hline
\end{tabular}

Hasil uji-t pada Tabel 3 menunjukkan bahwa nilai signifikansi uji-t data penguasaan konsep fisika dasar $2<$ taraf sifnifikansi 0.05 sehingga dapat disimpulkan bahwa penguasaan konsep fisika dasar 2 kelompok eksperimen lebih baik dibandingkan kelompok kontrol.. Hasil penelitian ini juga didukung oleh hasil penelitian Lovisa (2011), Rosengrant, $d k k$. (2009), Pedolefsky dan Finkelstein (2006) yang menyatakan bahwa penggunaan multi representasi pada pembelajaran fisika akan meningkatkan penguasaan konsep fisika peserta didik. Menurut hasil penelitian (Nguyen dan Robello, 2008; Kohl, $d k k .$, 2007) perbedaan penguasaan konsep disebabkan siswa pada kelompok eksperimen mempunyai kemampuan memecahkan masalah yang baik. Penyelesaian masalah yang baik akan berdampak pada penguasaan konsep yang baik (Nieminen, dkk., 2012; Stephans dan Clement, 2010) karena setiap representasi akan mendukung pemecahan masalah fisika siswa (Dufresne, 2004). 
Pada prose pembelajaran berbasis masalah dengan multiple representation siswa diawal pembelajaran dihadapkan pada masalah kongkrit yaitu masalah dalam kehidupan sehari-hari yang disajikan lebih dari satu representasi misalnya selain dijelaskan dengan kata-kata, permasalahan disajikan dalam dalam gambar atau video. Pemberian permasalahan dengan beberapa representasi membuat mahasiswa memahami permasalahan. Hal ini dilihat dari tidak ada pertanyaam atau permintaan tambahan informasi oleh mahasiswa setelah diberi permasalahan yang disajikan dengan menggunakan multiple

representation. Pemberian llebih dari satu representasi akan membantu mahasiswa membangun pemahamannya dalam memhami masalah (Ainsworth, 1999). Pada tahap diskusi kelompok dan latihan soal mahasiswa mengerjakan lembar kerja mahasiswa (LKM) dan soal yang dirancang agar mahasiswa menggunakan multiple representation dalam menjawab permasalahan yang sama. Penggunaan beberapa representasi dalam mengerjakan LKM akan membantu mahasiswa menyelesaikan masalah dan menganalisis apakah jawaban yang dituangkan dalam LKM sudah benar atau belum. Penggunaan lebih dari satu representasi akan membuat mahasiswa lebih sukses menyelesaikan masalah (Kohl dan Finkelstein, 2006).

Pada kelompok kontrol yaitu mahasiswa yang diajar dengan model pembelajaran berbasis masalah. Masalah yang diajukan diawal pembelajaran disajikan dalam satu representasi yaitu representasi verbal. Pembelajaran di kelompok kontrol adalah model pembelajaran berbasis masalah, permasalahan yang disajikan pada tahap penyajian masalah sama dengan kelompok eksperimen.. Pada saat pengajar mengajukan pertanyaan berkaitan dengan masalah, hanya sedikit siswa yang menjawab karena sebagian besar siswa masih terlihat kesulitan memahami masalah yang diajukan oleh guru karena masalah masih bersifat abstrak. Pada saat mengerjakan LKM dan latihan soal, mahasiswa pada kelas kontrol masih banyak mahasiswa yang meminta 
penjelasan tambahan terkait LKM maupun latihan soal terutama untuk soal-soal yang terkait pemahaman konsep.

Beberapa temuan penelitian pada kelas kontrol menjelaskan kesulitan mahasiswa saat memahami dan menyelesaikan masalah disebabkan karena pemahaman dan daya analisis masalah terhadap masalah rendah (Selcuk, 2010; Akinoglu dan Tandagon, 2007) sehingga mahasiswa memerlukan waktu yang lama dalam menyelesaikan masalah (Sahih dan Yorek, 2009; Kelly, 2007). Selain itu permasalahan yang muncul pada kelompok kontrol karena mahasiswa masih terbiasa mengerjakan soal matematik.Oleh karena itu diperlukan bantuan berpikir (cognitive scaffolds) dalam pelaksanaan model pembelajaran berbasis masalah untuk membantu mahasiswa memahami dan menyelesaikan masalah dengan baik (Jonassen, 2011).

\section{SIMPULAN}

Berdasarkan analisis data penelitian dan diskusi hasil penelitian dapat disimpulkan bahwa terdapat pengaruh penggunaan multiple representation pada pembelajaran berbasis masalah terhadap penguasaan konsep fisika dasar 2 mahasiswa fisika. Pengaruh multiple representation terlihat dari penguasaan konsep fisika kelas yang menggunakan multiple representation lebih tinggi dibandingkan dengan kelas yang tidak mengunakan multiple representation.

Pada penelitan selanjutnya sebaiknya diteliti pengaruh multiple representation untuk variabel yang lain misalnya untuk kemampuan berfikir kritis, kemampuan pemecahan masalah dan untuk model pembelajaran lain seperti pada model inkuiri, model learning cycle dan model yang lainnya.

\section{DAFTAR RUJUKAN}

Ainsworth, S. 1999. The Functions of Multiple Representations. Computers and Education, 33, 131-152.

Ainsworth, S. 2008. The Educational Value of Multiple representasi When Learning Complex Scientific Concept. In Gilbert, J. K., Reiner, M. 
and Nakhleh, M. (eds),

Visualization: Theory and

Practice in Science

Education, 191-208. New

York: Springe.

Akinoglu, O \& Tandagon, R. Ö. 2007. The Effects of Problem-Based Active Learning in Science

Education on Students' Academic Achievement, Attitude and Cocept Learning. Eurasia Journal of Mathematics, Science \& Technology Education, 2007, 3 (1), 71-81.

Arends, R. I. 2008. Learning to teach

( Belajar untuk Mengajar volume Idan 2). Edisi Ketujuh. Yogyakarta: Pustaka Pelajar.

Bilgin, I., Senocak, E., \& Sozbilir, M. 2009. The Effect of Problem-Based Learning: Pedagogy and Practice in the Engineering Classroom. Internasional Journal of Human and Social Science $3: 1$.

Direktorat Pembelajaran dan kemahasiswaan Dirjen Dikti Kemendikbud. 2014.
Panduan Penyusunan Capaian Pembelajaran Program Studi. http/belmawa.ristekdikti.go.i d

Docktor, J. L., Mestre, J. P., \& Ross, B.H. 2012. Impact of a Short Intervention on Novices' Categorization. Physical Review Special Topics Physics Education Research 8, 020102.

Folashade, A. \& Akinbola, A.O. 2009. Contructivist Problem Based Learning Technique and Academic Achievement of Physics Student with Low Ability Level in Nigerian Secondary School. Eurasian J. Phys. Chem. Educ. 1(1): 45-5.

Jonassen, D. 2011. Supporting Problem Solving in PBL. Interdisciplinary Journal of Problem Based Learning Vol. 5 Issue 2

Kelly, O. C. \& Finlaysona, O. E. 2007. Providing Solutions Through Problem-Based Learning for The Undergraduate 1 st Year Chemistry Laboratory. 
Chemistry Education

Research and Practice, 2007, 8 (3), 347-361.

Kohl, P. B., Rosengrant, D., \& Finkelstein,N. D. 2007. Strongly and weakly directed approaches to teaching multiple representation use in physics Physical Review Special Topics - Physics Education Research 3, 010108.

Lovisa, U. 2011. Penggunaan Pendekatan Multi Representasi Pada pembelajaran Konsep Gerak Untuk Meningkatkan Pemahaman Konsep Siswa dan Memperkecil Miskonsepsi siswa SMP. Tesis tidak diterbitkan. Bandung: Universitas Pendidikan Indonesia.

Nguyen, D \& Robello, N.S. 2009.

Students' Dificulties in Transfer of Problem Solving Across Representation. http//www.compadre.org/per/ item/detail.cfm?ID=9488. Diakses tanggal 1 Desember 2011
Nieminen, P., Savinainen, A., \& Viiri, J. 2012. Force Concept Inventory-Based MultipleChoice Test for Investigating Students' Representational Consistency. Physical Review Special Topics- Physics Education Research 6, 020109.

Pepper, C. 2009. Problem Based Learning in Science. Issue in Educational Research, 19 (2). Sahin, M. \& Yorek, N. 2009. A Comparison of ProblemBased Learning and Traditional Lecture students' Expectations and Course Grade in an Introductory Physics Classroom. Scientific Research ans Essay Vol. 4 (8), pp. 753-762.

Rosengrant, D., Heuvelen, A.V., \& Etkina, E. 2005. Case Study: Students' Use of Multiple Representations in Problem Solving. Proceeding of The 2005 PERC. 2005: AIP Conference Proceedings.

Selçuk, G. S. 2010. The Effects of Problem-Based Learning on Pre-Service Teachers' Achievement, Approaches 
$\begin{array}{ll}\text { and Attitudes } & \text { Towards } \\ \text { learning } & \text { Physics. }\end{array}$

International journal of the

Physicsal Sciences Vol. 5(6).

pp. 711-723.

Stephens, A. L. \& Clement, J.J. 2010. Documenting The Use of Expert Scientific

Reasoning Processes by High School Physics Students.

Physical Review Special

Topics-Physics Education

Research. 6(2),020122: 1-15.

Sundaygara, C. 2014. Pengaruh

Multi Representasi pada

Pembelajaran Berbasis

Masalah terhadap

Kemampuan Representasi

Siswa SMA. Jurnal FOTON,

Jurnal Fisika dan

Pembelajaran Volume 18

Nomor 2 Agustus 2014.

Sundaygara, C. 2014. Pengaruh

Multi Representasi pada

Pembelajaran Berbasis

Masalah terhadap Penguasaan

Konsep Fisika Siswa SMA.

Disajikan pada Prosiding

Seminar Nasional Volume 2

Nomor 1 Juni 2014 di

Universitas Kanjuruhan

Malang. 